\title{
Research on the effect of ginseng polysaccharide on apoptosis and cell cycle of human leukemia cell line K562 and its molecular mechanisms
}

\author{
WEI XIONG, JING LI, RONG JIANG, DANYANG LI, ZEHONG LIU and DILONG CHEN \\ Faculty of Basic Medical Sciences, Chongqing Medical University, Chongqing 400016, P.R. China
}

Received October 7, 2015; Accepted October 11, 2016

DOI: $10.3892 /$ etm.2017.4087

\begin{abstract}
Ginseng polysaccharide (GPS), a polymer of glucose and the primary constituent extracted from panax ginseng, has been documented to exert various pharmacological properties, including anti-tumor properties. To provide further insights into the anti-tumor functions of GPS, the present study was designed to investigate the effect of GPS on apoptosis and the cell cycle of human leukemia cell line K562 cells, and its underlying mechanisms. The results demonstrated that GPS could inhibit K562 cell proliferation and induce apoptosis in vitro in a concentration- and time-dependent manner. The transcription of P38 and c-Jun NH2-terminal kinase (JNK) mRNA were significantly augmented, while the transcription of extracellular signal-regulated kinase (ERK) mRNA were significantly reduced following treatment with GPS compared with the control group (all $\mathrm{P}<0.05$ ). In addition, GPS treatment markedly suppressed the expression of phosphorylated (p)-ERK, nuclear factor (NF)- $\mathrm{B}$ p65 and cyclin $\mathrm{D} 1$, and increased the synthesis of p-P38 and p-JNK protein expression, as evidenced by immunofluorescence and western blotting analyses. In conclusion, the results indicate that the GPS-mediated MAPK/NF- $\mathrm{B} /$ cyclin D1 signaling pathway serves a crucial role in cell cycle arrest and apoptosis of K562 cells.
\end{abstract}

\section{Introduction}

Leukemia is a group of hematological malignancies characterized by abnormal proliferation, decreased apoptosis and blocked differentiation of hematopoietic stem/progenitor cells (1). To date, the removal or deactivation of cancerous cells is the primary strategy of treating leukemia, and this is achieved by methods such as chemotherapy or bone marrow

Correspondence to: Dr Dilong Chen, Faculty of Basic Medical Sciences, Chongqing Medical University, 1 Yixueyuan Road, Yuzhong, Chongqing 400016, P.R. China

E-mail: xinmengyuandlc@163.com

Key words: ginseng polysaccharide, K562, apoptosis, cell cycle, mitogen-activated protein kinase, nuclear factor- $\mathrm{\kappa} \mathrm{B}$, cyclin D1 transplantation $(2,3)$. However, it has numbers of side effects and high toxicity. Therefore, apoptosis- and differentiation-inducing therapy seems to be a promising strategy for the treatment of leukemia, particularly in patients who cannot tolerate the intensity of chemotherapy and bone marrow transplantation. Thus, finding effective inducers that are free of general cytotoxicity and can be used to treat leukemia have clinical significance (4).

Traditional Chinese medicine (TCM) has been used in cancer treatment for a long time and its use is supported with scientific evidence (5). As a Chinese herbal medicine, panax ginseng is a very important TCM for 'invigorating qi'. The most effective ingredients of ginseng are the ginseng polysaccharide (GPS) that prevents and treats tumors. Previous studies have demonstrated that GPS could induce the inhibition of proliferation and differentiation of leukemia K562 cells in vitro. In addition, it has reported that ginseng induced apoptosis in human multiple myeloma cells (6). However, the effectiveness of GPS in a leukemia cell line remains to be explored and validated.

The human leukemia cell line K562 has been widely used for studies of leukemia, and is established from a patient with chronic myelogenous leukemia (7). In the present study, we adopted experimental hematology technologies to observe the effect of GPS on the inhibition of proliferation and induction of apoptosis in K562 cells and explore its underlying mechanisms.

\section{Materials and methods}

Drugs and reagents. GPS was purchased from Pude Pharmaceutical Co., Ltd. (Datong, China). Roswell Park Memorial Institute (RPMI)-1640 medium was obtained from Gibco (Thermo Fisher Scientific, Inc., Waltham, MA, USA). Fetal bovine serum (FBS) was purchased from Sijiqing Corporation (Hangzhou, China). Six-well plates and 96-well plates were provided by Costar (Cambridge, MA, USA). MTT related reagents were obtained from Sigma-Aldrich (Merck Millipore, Darmstadt, Germany). Annexin V-propidium iodide (PI) apoptosis detection kit was purchased from Zhongshan Biological Co. (Beijing, China). Rabbit monoclonal antibodies against extracellular signal-regulated kinase (ERK; sc-292838), phosphorylated (p)-ERK (sc-136521), P38 (sc-4708), p-P38 (sc-101758), c-Jun NH2-terminal kinase (JNK; 
sc-571) and p-JNK (sc-135642) were obtained from Santa Cruz Biotechnology, Inc. (Dallas, TX, USA). Rabbit monoclonal antibodies against cyclin D1 (EPR2241) and NF- $\mathrm{B}$ p65 (E379) were provided by Epitomics (Burlingame, CA, USA). Rabbit monoclonal antibody against $\beta$-actin (BA1039) was purchased from Wuhan Boster Biological Technology, Ltd., (Wuhan, China).

Cell culture. K562 cells were obtained from the Laboratory of the Faculty of Basic Medical Sciences, Chongqing Medical University (Chongqing, China). K562 cells were cultured in RPMI-1640 medium with 10\% FBS, penicillin $(100 \mathrm{U} / \mathrm{ml})$ and streptomycin $(100 \mu \mathrm{g} / \mathrm{ml})$ at $37^{\circ} \mathrm{C}$ in a humidified $5 \% \mathrm{CO}_{2}$ atmosphere, and were passaged every three days. GPS was sterilized by filter that was dissolved by RPMI-1640. Each test was repeated three times.

MTT assay. Viability of K562 cells was determined by MTT assay. At $90 \%$ confluence, K562 cells were adjusted to a density of $7 \times 10^{8}$ cells $/ 1$ and divided into the blank control group and the GPS group. The latter was subdivided into different final concentration groups with 25, 50, 100, 200, 400, 600 and $800 \mathrm{mg} / \mathrm{l} \mathrm{GPS}$. Cells were cultured in 96-well plates with $200 \mu \mathrm{l}$ culture medium for each well and incubated at $37^{\circ} \mathrm{C}$. After being cultured for 24,48 and $72 \mathrm{~h}, 5 \mathrm{~g} / 1 \mathrm{MTT}$ was added to each well and incubated at $37^{\circ} \mathrm{C}$ for $4 \mathrm{~h}$. Then, the cell suspension was centrifuged for $5 \mathrm{~min}$ at 1,200 $\mathrm{x}$ g and $4^{\circ} \mathrm{C}$ and the supernatants were removed. The crystals that had formed were dissolved by adding $150 \mu \mathrm{l}$ dimethyl sulfoxide to each well. After mixing, the absorbance of the cells was measured at $570 \mathrm{~nm}$ by a microplate reader. Experiments were performed in triplicate and the individual mean value was used for statistical analysis.

Measurement of cell cycle by flow cytometry (FCM). The control group was incubated in normal conditions and the GPS group was incubated with $400 \mathrm{mg} / \mathrm{l}$ GPS for $48 \mathrm{~h}$. K562 cells were washed twice with $0.02 \mathrm{M}$ PBS (pH 7.2) and fixed in $70 \%$ ethanol at $4^{\circ} \mathrm{C}$. Then, the fixative was removed, and RNase and PI was added for staining for $30 \mathrm{~min}$. PI-stained samples were analyzed using an Influx flow cytometer (BD Biosciences, Franklin Lakes, NJ, USA). Each sample consisted of $3 \times 10^{4}$ cells. The data were analyzed by CellQuest software (BD Biosciences), and the ratio of each phase of the cell cycle was calculated.

Annexin $V$ assay. The control group was cultured in normal conditions and the GPS group was cultured with $400 \mathrm{mg} / \mathrm{l} \mathrm{GPS}$ for $48 \mathrm{~h}$. K562 cells of each group were adjusted to a density of $1 \times 10^{6}$ cells $/ \mathrm{ml}$. Then, $1 \mathrm{ml}$ cell suspension was selected and centrifuged at $1,000 \times \mathrm{g}$ and $4^{\circ} \mathrm{C}$ for $5 \mathrm{~min}$. Then, the supernatants were removed, RNase was added, and samples were placed in a water bath at $37^{\circ} \mathrm{C}$ for $1 \mathrm{~h}$. Then, samples were placed in ice and incubated with $0.5 \mathrm{mg} / \mathrm{l} \mathrm{PI}$ and Annexin V. Finally, the cell apoptosis rate was detected by FCM.

Wright's staining. At $90 \%$ confluence, K562 cells were adjusted to the density of $7 \times 10^{8}$ cells/ 1 and divided into the blank control group and the GPS group. The control group was incubated in normal conditions and the GPS group was incubated with $400 \mathrm{mg} / \mathrm{l} \mathrm{GPS}$. After being cultivated for $48 \mathrm{~h}$ respectively, cells of the two groups were smeared on slides and treated with Wright's stain. Then, the morphology of cells was observed in the two groups under light microscopy.

Transmission electron microscopy (TEM). The control group was incubated in normal condition and the GPS group was incubated with $400 \mathrm{mg} / \mathrm{l} \mathrm{GPS}$. After being cultivated for $48 \mathrm{~h}$, fresh specimens of K562 cells were fixed by immersing them immediately in $2.5 \%$ glutaraldehyde fixative for $24 \mathrm{~h}$. Semi-thin sections $(60 \mathrm{~nm})$ were obtained by using an ultra-microtome. Then, the changes in ultrastructure of K562 cells were identified under TEM.

Immunofluorescence and confocal laser scanning microscopy. The control group was cultured in normal conditions and the GPS group was cultured with $400 \mathrm{mg} / \mathrm{l} \mathrm{GPS}$ for $48 \mathrm{~h}$. $\mathrm{K} 562$ cells were centrifuged at $1,000 \mathrm{x} g$ and $4^{\circ} \mathrm{C}$ for $5 \mathrm{~min}$ and then placed on slides. Them, slides were fixed with $4 \%$ paraformaldehyde at $4^{\circ} \mathrm{C}$ for $20 \mathrm{~min}$ and washed three times with PBS for 5 min each. After blocking with $0.5 \%$ bovine serum albumin (Beyotime Institute of Biotechnology, Haimen, China) at room temperature for $30 \mathrm{~min}$, slides were incubated with mouse anti-p-ERK, p-P38, p-JNK and rabbit anti-NF- $\kappa$ B p65 and cyclin D1 (all at 1:150) overnight at $4^{\circ} \mathrm{C}$. Then, slides were washed three times with PBS, and treated with fluorescein isothiocyanate goat anti-mouse (1:100; BA1105) or rabbit (1:100; BA1101; both Wuhan Boster Biological Technology, Ltd.) $\mathrm{IgG}$ for $40 \mathrm{~min}$ at room temperature in the dark. After being mixed with PI for $1 \mathrm{~min}$, slides were again rinsed with PBS three times, mounted with 50\% glycerol and stored in the dark. Immunofluorescence was examined with a Leica Sp2 confocal microscope.

Western blot analysis. Expression of ERK, p-ERK, P38, p-P38, JNK, p-JNK, NF- $\kappa \mathrm{B}$ p 65 and cyclin D1 proteins was measured by western blotting. K562 cells were divided into the blank control group and the experimental group. In the experimental group, K562 cells were treated with $400 \mathrm{mg} / \mathrm{l} \mathrm{GPS}$ at $37^{\circ} \mathrm{C}$ for $6,18,24,48$ and $72 \mathrm{~h}$. Briefly, cells were washed twice with PBS. Then, cell pellets were resuspended in lysate buffer, lysed on ice for $20 \mathrm{~min}$, and then centrifuged at 12,000 x g at $4{ }^{\circ} \mathrm{C}$ for $15 \mathrm{~min}$ to remove nuclei and unbroken cells. Aliquots of supernatants containing $4 \mu \mathrm{g} / \mu \mathrm{l}$ of protein were suspended in SDS sample buffer and boiled for $5 \mathrm{~min}$. Proteins were separated by $10 \%$ SDS-polyacrylamide gel electrophoresis. The resulting gels were equilibrated in transfer buffer [25 mmol/1 Tris-HCl, $192 \mathrm{mmol} / \mathrm{l}$ glycine and 20\% methanol (pH 8.3)], and the proteins were transferred electrophoretically to polyvinylidene difluoride membranes and incubated for $1 \mathrm{~h}$ with PBS containing 5\% skimmed milk and 0.05\% Tween- 20 . Then, the membranes were incubated with antibodies against ERK, P38, JNK (all at 1:800), p-ERK, p-P38, p-JNK (all at

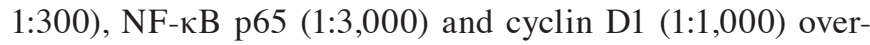
night at $4^{\circ} \mathrm{C}$. Specific biotinylated goat anti-rabbit antibodies (1:1,000; 7074P2; Cell Signalling Technologies, Inc., Danvers, MA, USA) were used to detect the primary antibodies for $1 \mathrm{~h}$ at room temperature. Antibodies against $\beta$-actin (1:500) were used for reference. Blots were developed with an ECL kit (WBKLS0100; EMD Millipore, Billerica, MA, USA) 
according to the manufacturer's instructions. The results were analyzed by Photoshop version 6.0 software (Adobe Systems, Inc., San Jose, CA, USA).

RNA isolation and reverse transcription-polymerase chain reaction $(R T-P C R)$. Total RNA was extracted from $K 562$ cell using TRIzol (Invitrogen; Thermo Fisher Scientific, Inc.), and quality was verified by resolving samples using $1 \%$ agarose gel electrophoresis. The following primers were used: ERK forward, 5'-CCCAAATGCTGACTCCAAAG-3', and reverse 5'-TCGGGTCGTAATACTGCTCC-3'; P38 forward 5'-ACC GTTTCAGTCCATCATTC-3', and reverse 5'-GTCAGCTTC TGGCACTTCAC-3'; JNK forward, 5'-CAAGCAGTTAGA TGAAAGGGAA-3', and reverse 5'-CAGACGACGATGATG ATGGA-3'; and GAPDH forward 5'-ACAGCCTCAAGATCA TCAGCA-3', and reverse 5'-TGAGTCCTTCCACGATAC CAA-3'. The PCR conditions were as follows: Denaturing at $94^{\circ} \mathrm{C}$ for $5 \mathrm{~min}, 94^{\circ} \mathrm{C}$ for $30 \mathrm{sec}, 58^{\circ} \mathrm{C}$ for $30 \mathrm{sec}$ and $72^{\circ} \mathrm{C}$ for $20 \mathrm{sec}$; target genes underwent 34 cycles and GAPDH underwent 28 cycles at $72^{\circ} \mathrm{C}$ for $10 \mathrm{~min}$. PCR products were resolved by using $2 \%$ agarose gel electrophoresis for $40 \mathrm{~min}$. The results were observed under an ultraviolet lamp, photos were captured and the optical densities of bands were quantified and analyzed using UVI-Map V.99 software (UVItec, Ltd., Cambridge, UK).

Statistical analysis. The data are presented as the mean \pm standard deviation. Data were analyzed using SPSS version 13.0 statistical package (SPSS, Inc., Chicago, IL, USA). One-way analysis of variance and Student's t-test were used with the Bonferroni method to determine statistically significant differences. $\mathrm{P}<0.05$ was considered to indicate a statistically significant difference.

\section{Results}

Growth inhibition and cell cycle perturbation were induced by GPS. The results indicated that exposure of K562 cells to GPS at different concentrations $(25,50,100,200,400$, 600 and $800 \mathrm{mg} / \mathrm{l}$ ) for 24, 48 and $72 \mathrm{~h}$ caused significant inhibition to the proliferation of cells in a dose-dependent manner ( $\mathrm{P}=0.03$; Fig. 1A). Exposure to $400 \mathrm{mg} / \mathrm{l}$ GPS for $48 \mathrm{~h}$ resulted in $\mathrm{IC}_{50}$. Therefore, $400 \mathrm{mg} / \mathrm{l} \mathrm{GPS}$ treatment for 48 $\mathrm{h}$ was used in the following experiments of K562 cells. In addition, it was identified that the G0/G1 phase of the cell cycle increased significantly $(\mathrm{P}=0.02)$, while the $\mathrm{G} 2+\mathrm{M}$ and $\mathrm{S}$ phases of the cell cycle decreased significantly $(\mathrm{P}=0.02)$ after GPS $(400 \mathrm{mg} / \mathrm{l})$ treatment, in a time-dependent manner (Fig. 1B). These results demonstrated that GPS could inhibit K562 cell proliferation and arrest the cell cycle in the G0/G1 phase.

GPS triggers apoptosis in K562 cells. The percentage of apoptotic cells following treatment with GPS at $400 \mathrm{mg} / \mathrm{l}$ for 24 , 48 and $72 \mathrm{~h}$ in K562 cells were analyzed by flow cytometry. Results of Annexin V/PI double staining confirmed that after adding $400 \mathrm{mg} / \mathrm{l} \mathrm{GPS}$ for 24 (23.00 $\pm 0.65 \%), 48(43.85 \pm 0.87 \%)$ and $72 \mathrm{~h}(49.56 \pm 0.93 \%)$ the apoptosis rates of K562 cells were significantly increased compared with the control group $(3.82 \pm 0.23 \%$; P $<0.05$; Fig. 2). Furthermore, TEM was used to observe the changes in ultrastructure morphology in K562 cells upon GPS treatment $(400 \mathrm{mg} / \mathrm{l}$ for $48 \mathrm{~h})$. The results showed that increased blebbing, cell shrinkage, nuclear fragmentation, chromatin condensation and the formation of apoptotic bodies were present in GPS-treated K562 cells in comparison with untreated control cells (Fig. 3).

Morphological changes. In the control group, the nuclear volume was relatively high. The nucleoli were clearly visible and the nuclei:cytoplasm ratio was high. As can be observed in Fig. 4, the cytoplasm showed strong basophilia with specialized granules (Fig. 4A). Compared with the control group, the cell volume and nuclear diameter in the GPS group were smaller after $48 \mathrm{~h}$ (Fig. 4B; black arrows). The cytoplasm was abundant and the nuclei:cytoplasm ratio was decreased. Interestingly, in the GPS group a number of cells showed nuclear division, and the basophilia in the cytoplasm was weakened (Fig. 4B; red arrows).

GPS reduces the expression of $p-E R K, N F-B p 65$ and CyclinD1, while increase the expression of $P-P 38$ and $P$-JNK in K562 cells. After treatment with $400 \mathrm{mg} / \mathrm{l}$ GPS for $48 \mathrm{~h}$, the expression of p-ERK (Fig. 5), NF-kB p65 (Fig. 6) and cyclin D1 (Fig. 7) protein evidently decreased, while the expression of p-P38 (Fig. 8) and P-JNK (Fig. 9) protein increased, particularly the protein in the nucleus. Moreover, as shown in Fig. 6, the expression of NF-кB p65 decreased markedly and was transferred from the nucleus to the cytoplasm and cell membrane in K562 cells. After being incubated with $400 \mathrm{mg} / \mathrm{l}$ GPS for $0,6,18,24,48$ and $72 \mathrm{~h}$, it was observed that the variation of p-ERK, NF-kB p65, cyclin D1, p-P38 and p-JNK protein were expressed in a time-dependent manner. However, the expression of ERK, P38 and JNK did not change, as evidenced by western blotting analysis (Fig. 10).

GPS upregulated the transcription of P38 and JNK $m R N A$, and downregulated the transcription of ERK $m R N A$. After treatment with $400 \mathrm{mg} / \mathrm{l} \mathrm{GPS}$ for $48 \mathrm{~h}$, the transcription of ERK mRNA was significantly decreased $(\mathrm{P}<0.05)$, while the transcription of P38 and JNK mRNA were significantly increased $(\mathrm{P}<0.05 ;$ Fig. 11). In conclusion, these results indicate that GPS-mediated MAPK/NF- $\mathrm{kB} /$ Cyclin D1 signaling pathway played a crucial role in the cell cycle arrest and apoptosis of K562 cells.

\section{Discussion}

In the present study, human erythroleukemia cell line K562 cells were cultured from chronic myelogenous leukemia patients' pleural fluid. Since drugs can affect erythroid, granulocyte-monophyletic and megakaryocytic cell differentiation, it is an ideal model for the study of cell proliferation and differentiation, since its biological features are similar to the normal hematopoietic stem cell (CFU-Mix) (8). In the current study, the primary ingredient of ginseng, GPS, was demonstrated to inhibit proliferation and induce cell apoptosis of K562 cells. Furthermore, it was observed that GPS induces apoptosis and differentiation of K562 cells by influencing the MAPK signaling pathway.

Ras-MAPK signal transduction pathway is a type of serine/threonine protein kinase in cells, and serves a key 
A

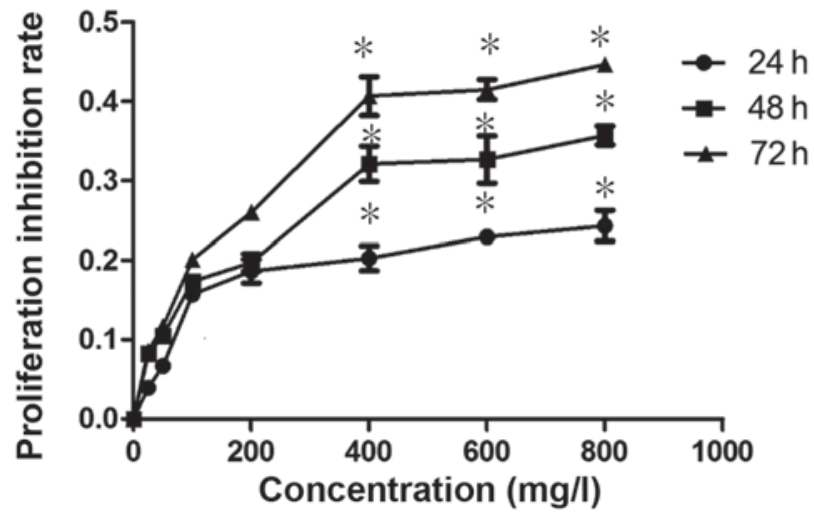

B

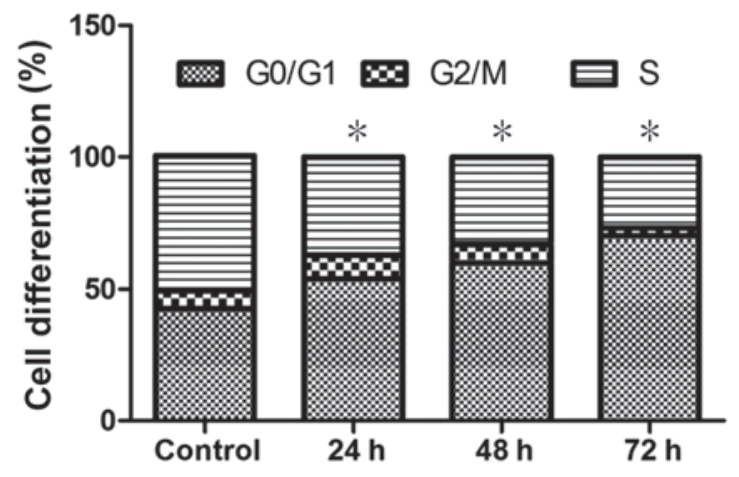

Figure 1. Effect of GPS on the cell cycle and proliferation of K562 cells. (A) Survival assay (MTT) was performed with the K562 cell line after treatment with GPS (20-800 mg/l) for 24, 48 and $72 \mathrm{~h}$. ${ }^{*} \mathrm{P}<0.05$ vs. untreated cells in suspension or in adhesion. Data are presented as the mean \pm standard error ( $\mathrm{n}=6$ ). (B) K562 cells were treated with $400 \mathrm{mg} / \mathrm{l} \mathrm{GPS}$ for 24,48 and $72 \mathrm{~h}$. ${ }^{*} \mathrm{P}<0.05$ vs. the blank control group. Data are presented as the mean \pm standard error ( $\mathrm{n}=3$ ). GPS, ginseng polysaccharide.
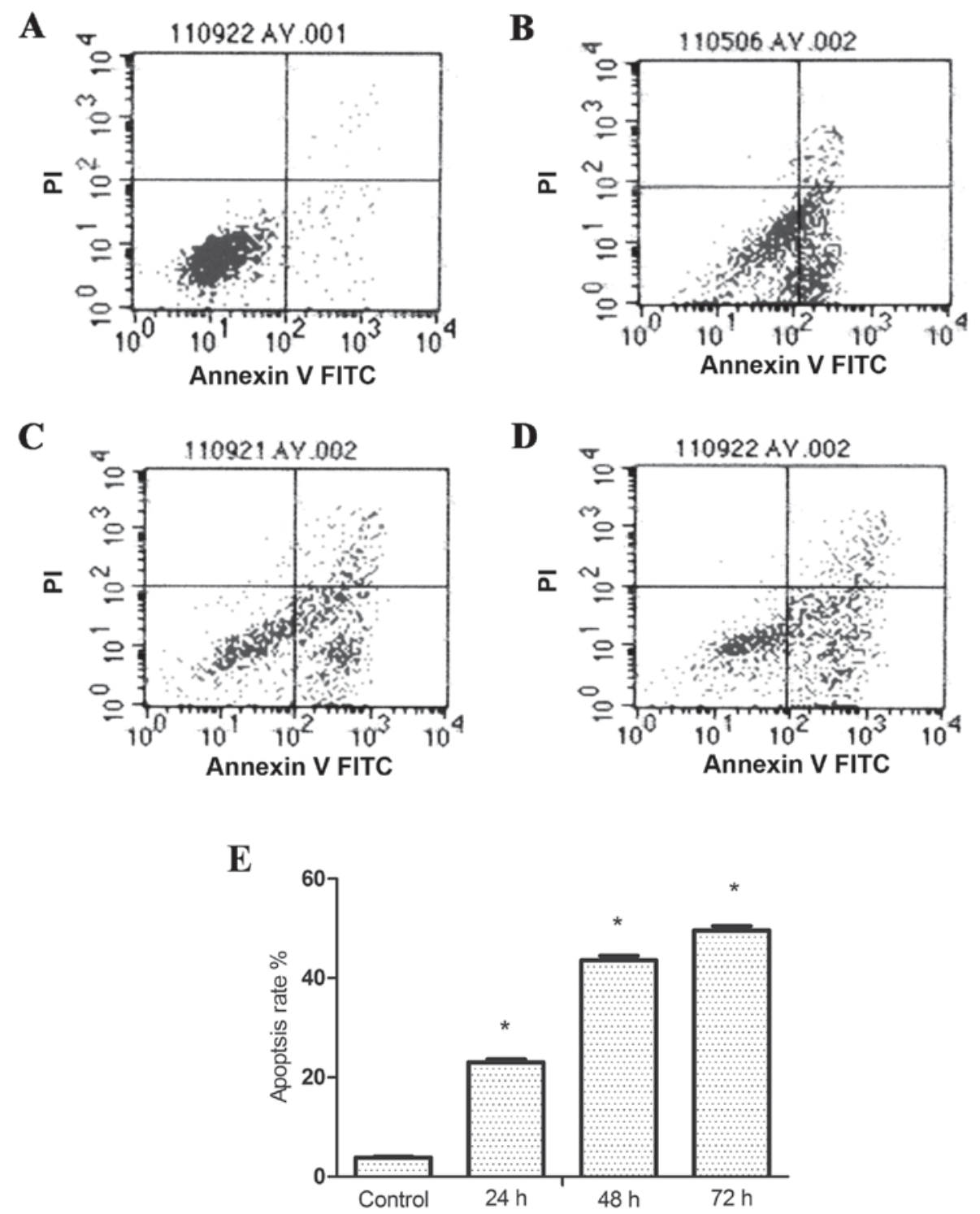

Figure 2. Effects of GPS on the apoptosis of K562 cells. The (A) control group and GPS groups treated with $400 \mathrm{mg} / 1 \mathrm{GPS}$ and incubated for (B) 24 (C) 48 and (D) $72 \mathrm{~h}$ were analyzed for apoptosis by Annexin V FITC and PI staining by flow cytometric analysis (E). Annexin V-, PI- cells are live cells, Annexin V+, PI- cells are early apoptotic cells, and Annexin V+, PI+ cells are late apoptotic cells. * $\mathrm{P}<0.05$ compared with the control group. FITC, fluorescein isothiocyanate; GSP, ginseng polysaccharide; PI, propidium iodide. 

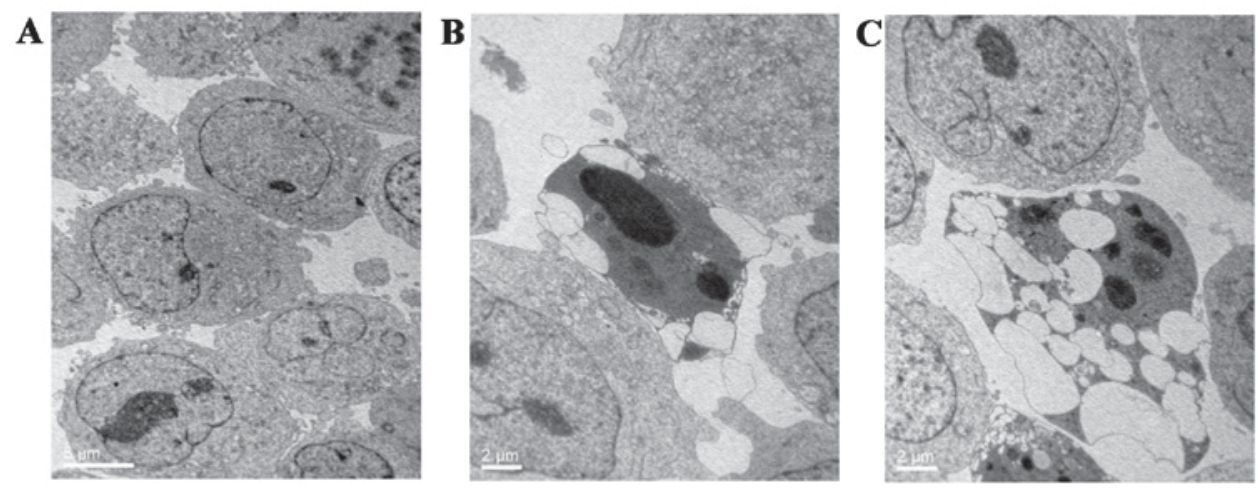

Figure 3. Ultrastructure of K562 cells by TEM. Representative images showing he changes in ultrastructure of K562 cells by TEM in (A) the control group at magnification, $\times 3,500$, or the GPS group at (B) magnification $\times 5,000$ and (C) $\times 3,500$. The control group were cultured in normal conditions and the GPS group were cultured with $400 \mathrm{mg} / \mathrm{l} \mathrm{GPS}$ for $48 \mathrm{~h}$. GPS, ginseng polysaccharide.

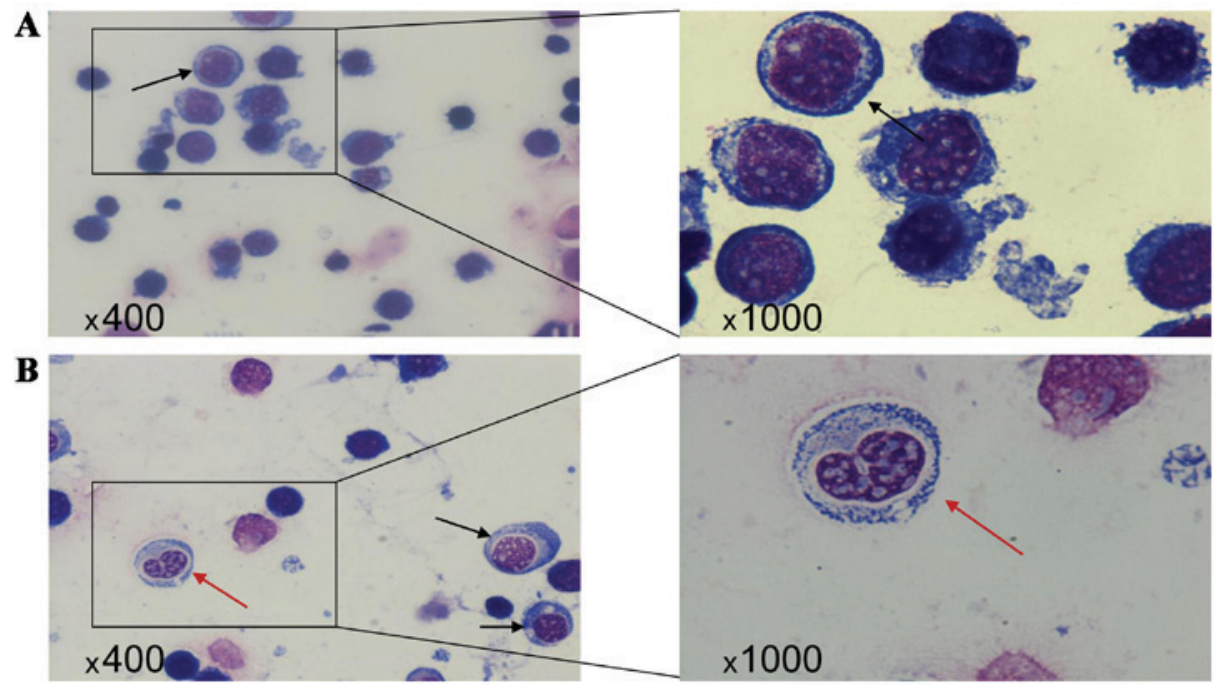

Figure 4. Effect of GPS on K562 cells observed by Wright's stain. (A) K562 cells in the control group. The black arrows indicate that the cell volume and nuclear diameter in the GPS group were smaller after $48 \mathrm{~h}$. (B) K562 cells treated with $400 \mathrm{mg} / 1 \mathrm{GPS}$ for $48 \mathrm{~h}$. The red arrows indicate that, in the GPS group, a number of cells showed nuclear division, and the basophilia in the cytoplasm was weakened. Left half of the figure, $x 400$ magnification; right half of the figure, $\mathrm{x} 1,000$ magnification.

role in the pathogenesis of chronic myeloid leukemia (9). The activation of MAPK by means of conservative 3-level kinase cascade, the kinase of MAPK kinase (MAPKKK, MAP3K, MEKK or MKKK) activates MAPK kinase (MAPKK, MAP2K, MEK or MKK), then MAPK kinase activates MAPK, and the performance of this activation reaction is through successive phosphorylation (10). The activated MAPK participates in a number of cell responses, such as maintaining cell survival and inducing apoptosis (11). The MAPK family primarily includes three groups, including ERK1/2, P38 mitogen-activated protein kinase, P38 and JNK. Among them, the ERK1/2's primary response is the stimulation of growth factors and the mediating of the cell proliferation signal (12). If it remains activated, it can cause cells to undergo malignant transformation. One study showed that the anti-apoptotic features of the K562 cell line associated with activity of ERK were more pronounced than in control cells, and that inhibition of the activity of ERK can cause K562 cell apoptosis (13). In addition, JNK and P38 primarily mediate cells apoptosis, differentiation and inflammation caused by emergency stimuli (14,15). This demonstrates that the MAPK system controls the cell proliferation, differentiation and apoptosis processes, and that a disruption of any one of them can cause excessive cell growth and result in cancer.

In previous studies, it was demonstrated that GPS can promote the proliferation and differentiation of pluripotent hemopoietic stem cells (CFU-Mix) (16-19). Meanwhile, increasing attention has been paid to the role of ginseng in cancer therapies. The primary strategy of the treatment for leukemia is to inhibit the proliferation of abnormal differentiated cells. In this study, different concentrations of GPS were used to examine K562 cells in vitro, and the effect of GPS was observed on the proliferation of K562 cells. MTT assay showed that GPS significantly inhibited the proliferation of K562 cells in a time- and dose-dependent manner. By analyzing the experimental results, it was concluded that GPS promoted normal hematopoiesis, and inhibited the proliferation of leukemic cells. It is hoped that the conclusion will provide theoretical basis and positive prospects for clinical applications. 
$\mathbf{A}$
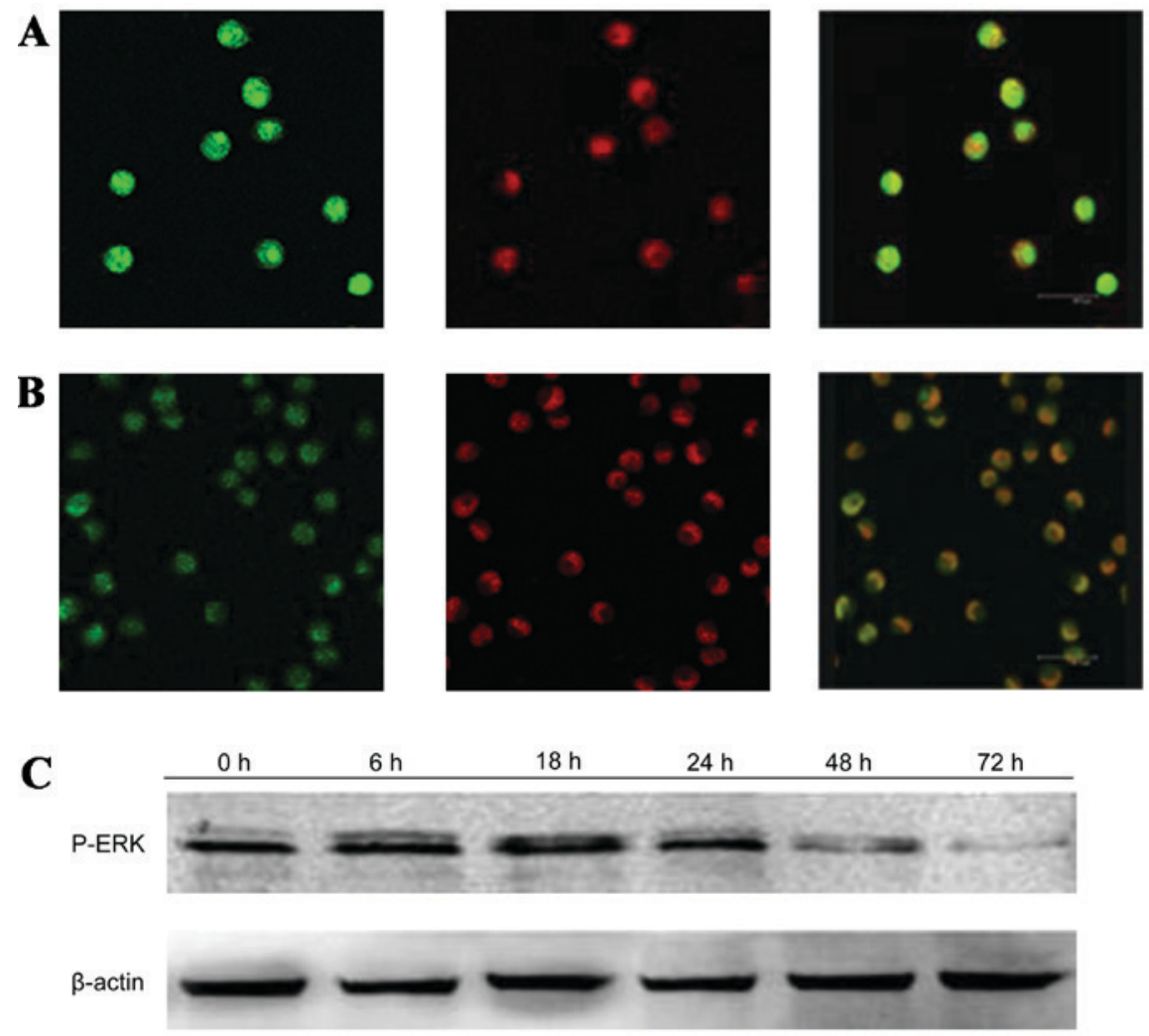

Figure 5. Effect of GPS on p-ERK protein expression in K562 cells. P-ERK was identified by immunofluorescence double staining in (A) the control group and (B) the GPS group, treated with $400 \mathrm{mg} / 1$ GPS. Green fluorescence, protein; red fluorescence, nucleus. (C) p-ERK protein analyzed by western blotting, following the treatment of cells with $400 \mathrm{mg} / \mathrm{l} \mathrm{GPS}$ for different time periods. GPS, ginseng polysaccharide; p-ERK, phosphorylated extracellular signal-regulated kinase.
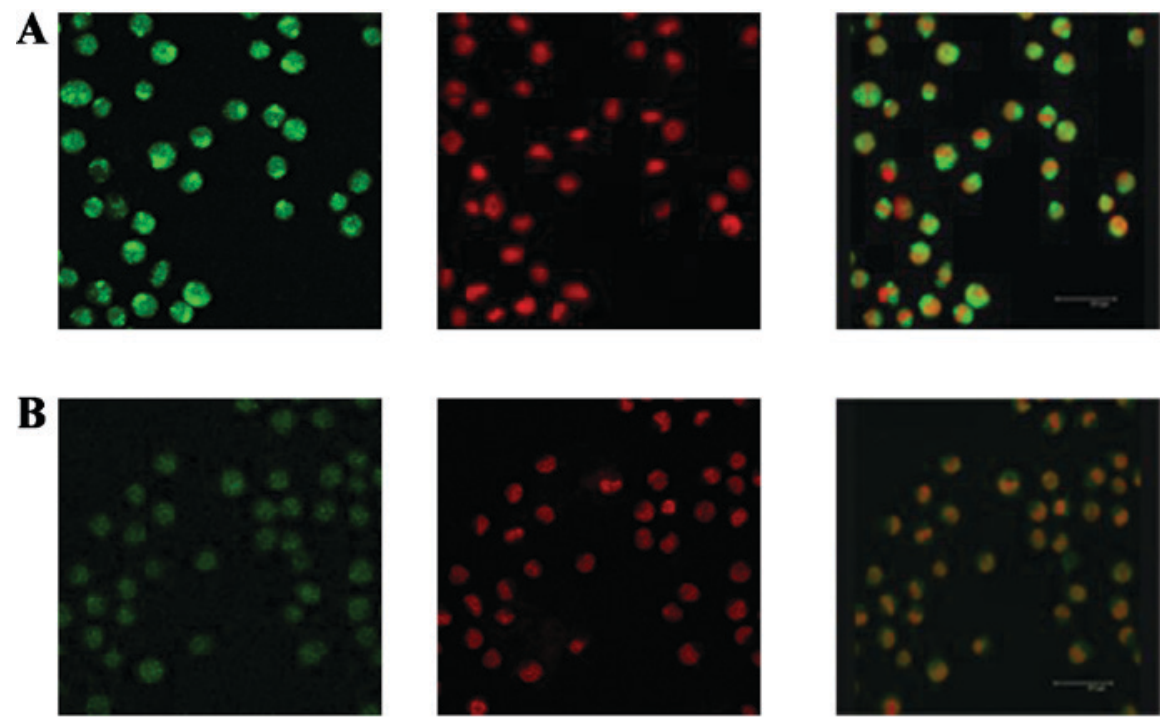

C

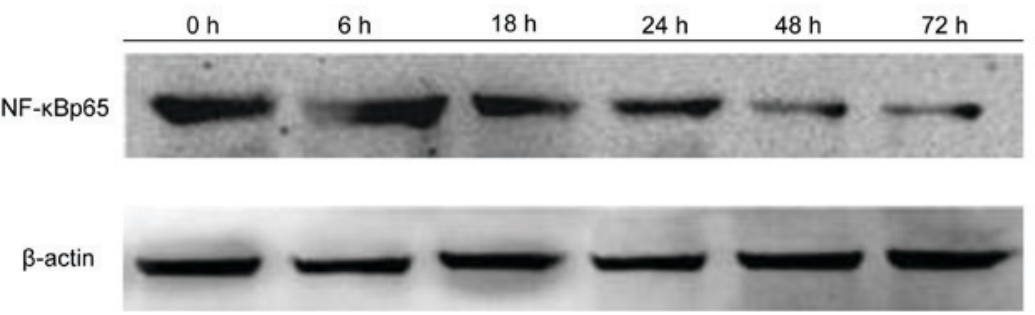

Figure 6. Effect of GPS on p-P38 protein expression in K562 cells. P-P38 was identified by immunofluorescence double staining in (A) the control group and (B) the GPS group, treated with $400 \mathrm{mg} / \mathrm{l}$ GPS. Green fluorescence, protein; red fluorescence, nucleus. (C) p-P38 protein analyzed by western blotting, following the treatment of cells with $400 \mathrm{mg} / 1$ GPS for different time periods. GPS, ginseng polysaccharide; p-P38, phosphorylated P38. 

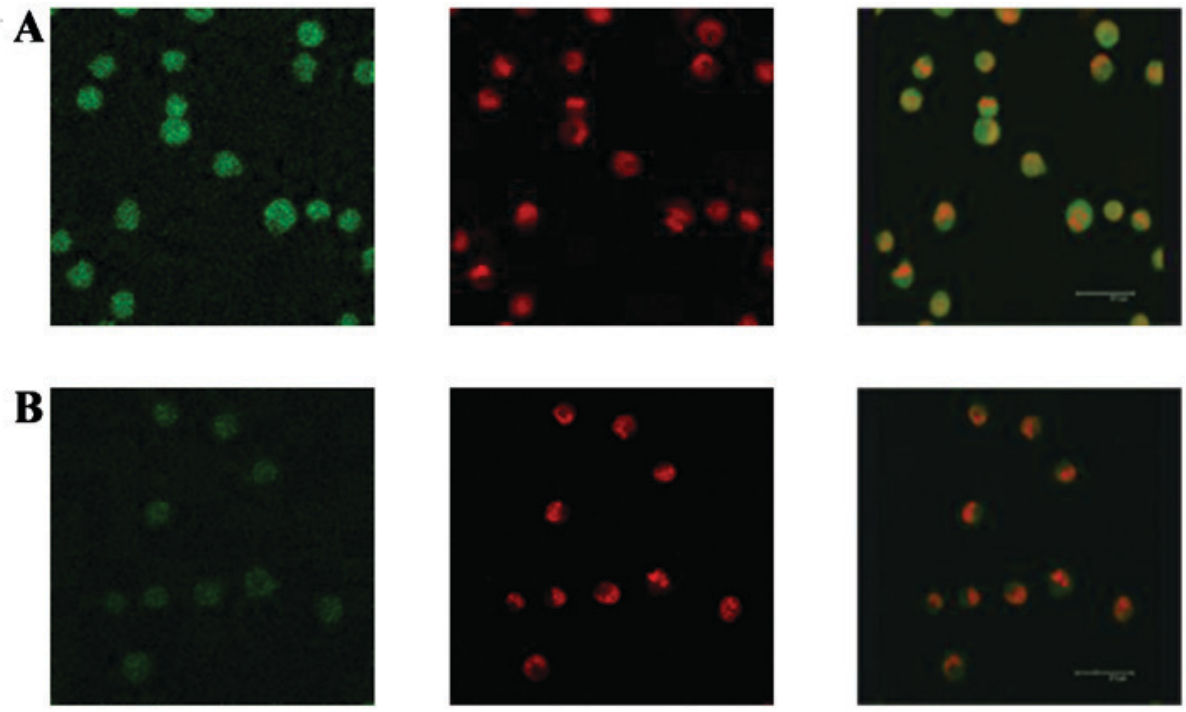

C

$\mathrm{Oh} \quad 6 \mathrm{~h}$

$6 \mathrm{~h} \quad 18 \mathrm{~h}$

$24 \mathrm{~h}$

$48 \mathrm{~h} \quad 72 \mathrm{~h}$

CyclinD1

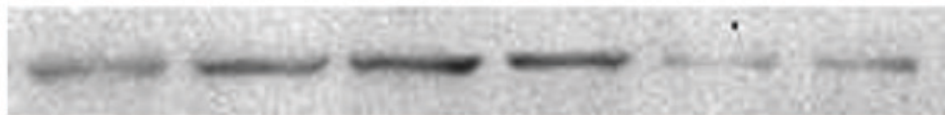

$\beta$-actin

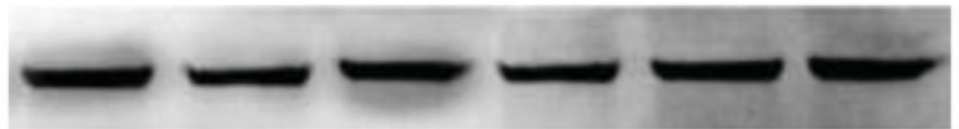

Figure 7. Effect of GPS on p-JNK protein expression in K562 cells. P-JNK was identified by immunofluorescence double staining in (A) the control group and (B) the GPS group, treated with $400 \mathrm{mg} / \mathrm{l} \mathrm{GPS}$. Green fluorescence, protein; red fluorescence, nucleus. (C) p-JNK protein analyzed by western blotting, following the treatment of cells with $400 \mathrm{mg} / \mathrm{l}$ GPS for different time periods. GPS, ginseng polysaccharide; p-JNK, phosphorylated c-Jun N-terminal kinase.

$\mathbf{A}$
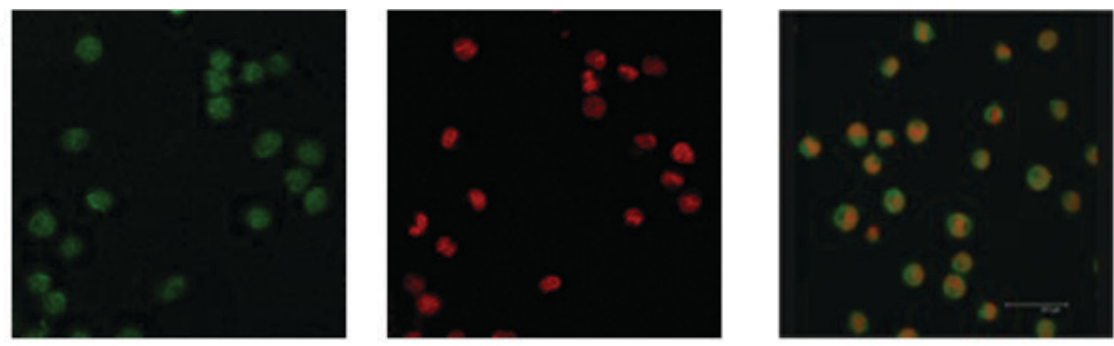

B
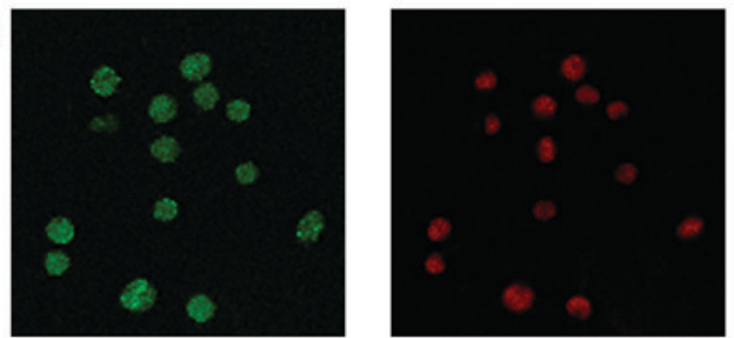

C

$0 \mathrm{~h} \quad 6 \mathrm{~h}$

$18 \mathrm{~h}$

$24 \mathrm{~h}$

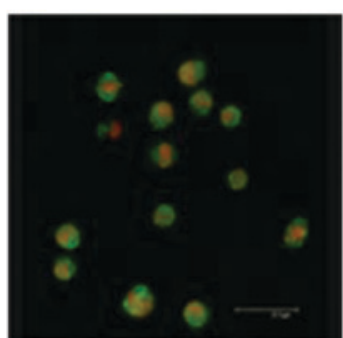

$48 \mathrm{~h}$

$72 \mathrm{~h}$

P-P38

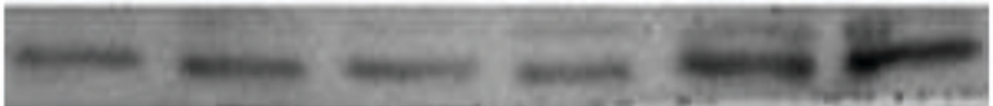

$\beta$-actin

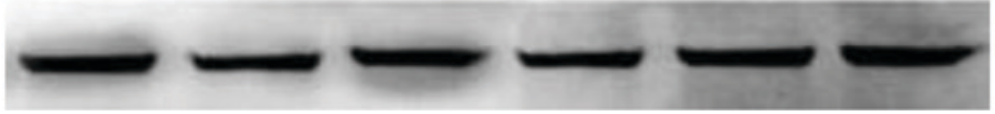

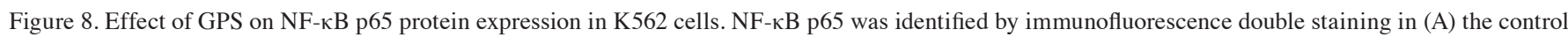
group and (B) the GPS group, treated with $400 \mathrm{mg} / 1$ GPS. Green fluorescence, protein; red fluorescence, nucleus. (C) NF- $\mathrm{kB}$ p65 protein analyzed by western blotting, following the treatment of cells with $400 \mathrm{mg} / 1$ GPS for different time periods. GPS, ginseng polysaccharide; NF- $\mathrm{B}$ p65, nuclear factor- $\mathrm{BB}$ p65. 

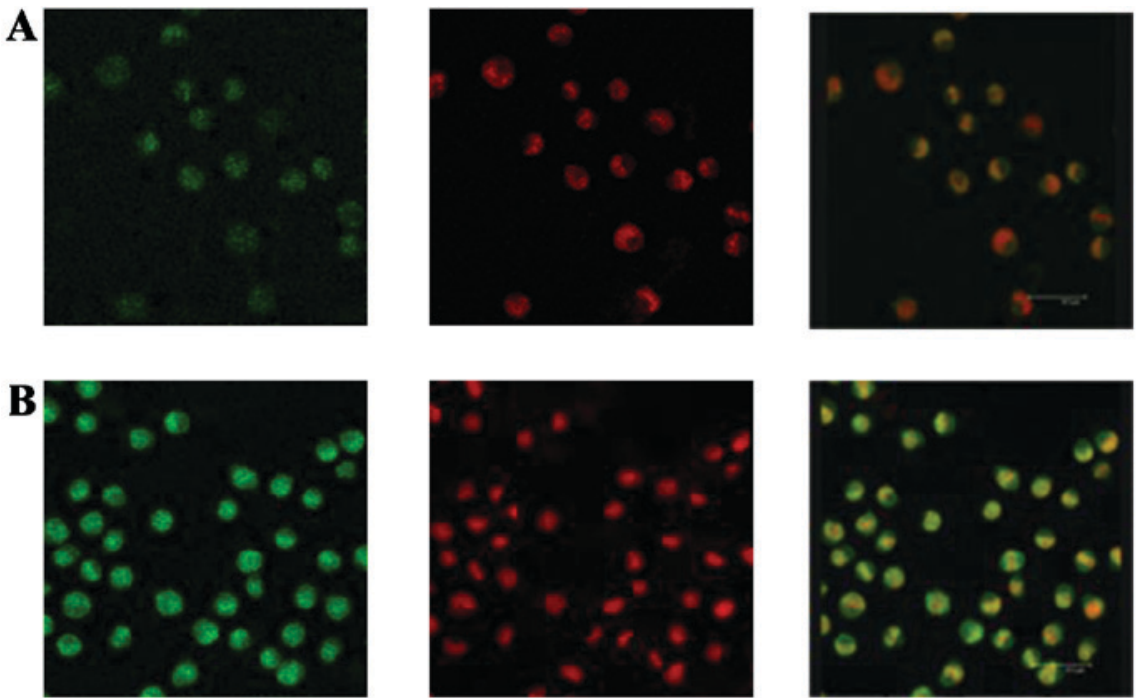

C

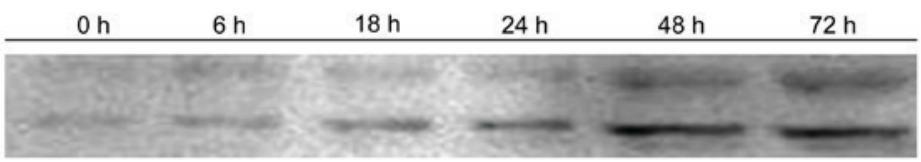

$\beta$-actin

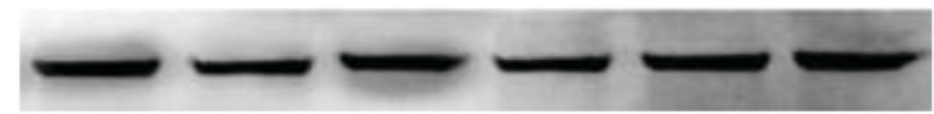

Figure 9. Effect of GPS on cyclin D1 protein expression in K562 cells. Cyclin D1 was identified by immunofluorescence double staining in (A) the control group and (B) the GPS group, treated with $400 \mathrm{mg} / \mathrm{l} \mathrm{GPS}$. Green fluorescence, protein; red fluorescence, nucleus. (C) Cyclin D1 protein analyzed by western blotting, following the treatment of cells with $400 \mathrm{mg} / 1 \mathrm{GPS}$ for different time periods. GPS, ginseng polysaccharide.

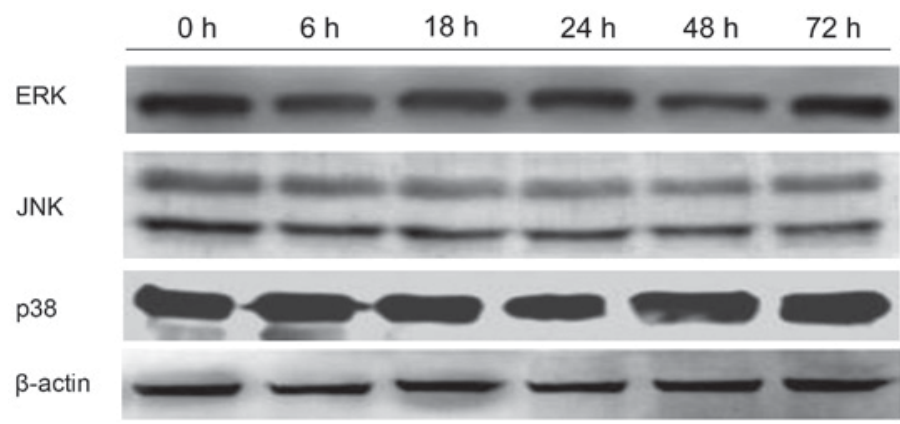

Figure 10. Effect of GPS on ERK, P38 and JNK protein expression in K562 cells by western blotting. The blots showed no obvious change in protein expression following treatment of K562 cells with GPS at $400 \mathrm{mg} / \mathrm{l}$. ERK, extracellular signal-regulated kinase; GSP, ginseng polysaccharide; JNK, c-Jun N-terminal kinase.

Apoptosis is the process of programmed cell death that may occur in multicellular organisms. Biochemical events lead to characteristic cell changes and death. Unlike necrosis, apoptosis produces cell fragments called apoptotic bodies that phagocytic cells are able to engulf and quickly remove before the contents of the cell can spill out onto surrounding cells and cause damage. Apoptosis is a multi-step, multi-pathway cell-death program that is inherent in every cell of the body. In cancer, the apoptosis cell division ratio is altered. Cancer treatment by chemotherapy and irradiation kills target cells primarily by inducing apoptosis. In the present study, a large number of apoptotic cells were observed by TEM in the $400 \mathrm{mg} / \mathrm{l}$ GPS group after $48 \mathrm{~h}$. These changes included blebbing, cell shrinkage, nuclear fragmentation, chromatin condensation and the formation of apoptotic bodies. Therefore, it was demonstrated that GPS can induce apoptosis of K562 cells and arrest tumor progression.

MAPK signaling pathway regulates the survival, growth and apoptosis of cells (20). The abnormal activation of ERK in tumor cells can be observed. Therefore, blocking the ERK signaling pathway is an important method for cancer treatment. P38 and JNK serve a pivotal role in apoptosis (21). In the present study, results of immunofluorescence demonstrated that the protein expression of p-ERK was located in the nucleus and cytoplasm in the control group. Compared with the control group, expression of p-ERK protein, particularly protein in the nucleus, decreased markedly in the $400 \mathrm{mg} / 1$ GPS group at $48 \mathrm{~h}$. The protein expression of p-P38 was located in the nucleus and cytoplasm in the control group. 

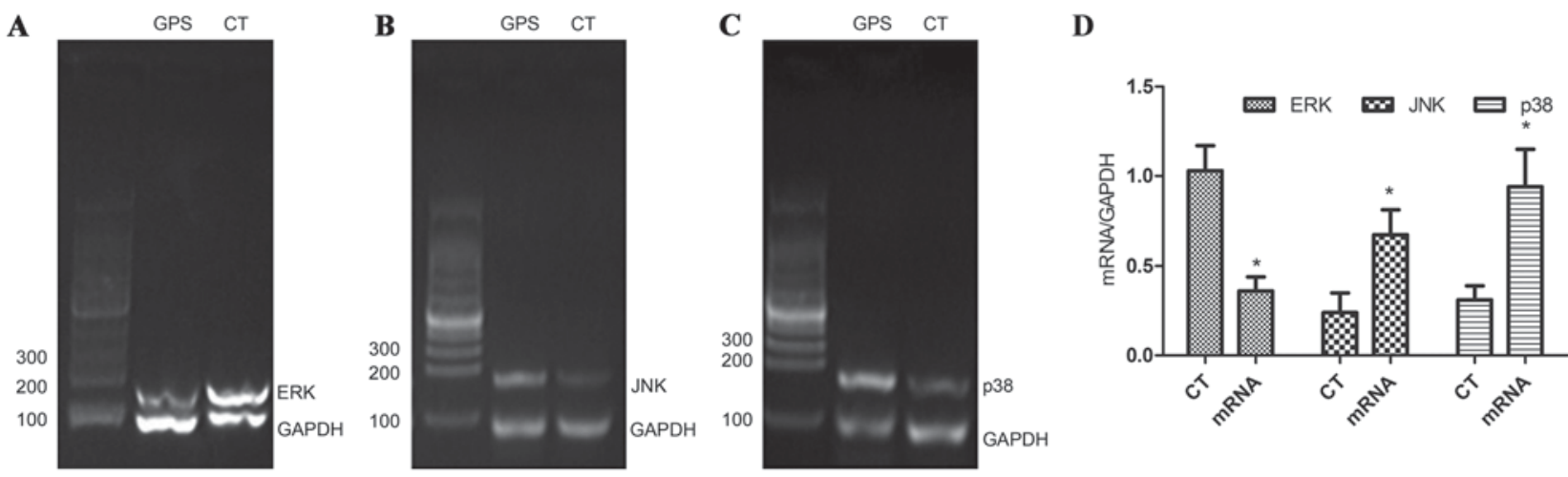

Figure 11. Effect of GPS on the expression of (A) ERK, (B) P38 and (C) JNK mRNA in K562 control cells, and K562 cells treated with 400 mg/l GPS for 48 h. mRNA was determined by semi-quantitative reverse transcription-polymerase chain reaction and normalized to GAPDH (D). Data are means \pm standard error ( $\mathrm{n}=3$ each group). "P<0.05. ERK, Extracellular signal-regulated kinase; GSP, ginseng polysaccharide; JNK, c-Jun N-terminal kinase.

Compared with the control group, the protein expression of p-P38, particularly protein in the nucleus, increased markedly in the $400 \mathrm{mg} / \mathrm{l} \mathrm{GPS}$ group at $48 \mathrm{~h}$. The protein expression of p-JNK was located primarily in the cytoplasm in the control group. Compared with the control group, protein expression of p-JNK, particularly in the nucleus, increased significantly in the $400 \mathrm{mg} / \mathrm{l}$ GPS group at $48 \mathrm{~h}$.

Results of RT-PCR confirmed that the expression of ERK mRNA in the $400 \mathrm{mg} / \mathrm{l} \mathrm{GPS}$ group after $48 \mathrm{~h}$ was lower than that in the blank control group, while the expression of P38 and JNK mRNA was higher than that in the blank control group. Results of western blotting demonstrated that the expression of ERK, P38 and JNK has not changed markedly, while p-ERK decreased, and p-P38 and p-JNK were increased, compared with control group, following the treatment of cells with $400 \mathrm{mg} / \mathrm{l} \mathrm{GPS}$ for different time periods. A number of studies have shown that activated MAPK, namely p-ERK, p-P38 and p-JNK, participate in the processes of gene transcription and the induction of apoptosis $(20,22)$. Hence, the effect of GPS on the apoptosis of K562 cells may be caused by the phosphorylation of MAPK and the activation of downstream pro-apoptotic proteins, followed by changes in the location of p-ERK, p-P38 and $\mathrm{p}-\mathrm{JNK}$.

The NF- $\kappa \mathrm{B}$ signaling pathway is a key pathway in the occurrence and progression of tumors. Anomalous activation of the NF- $\mathrm{NB}$ signaling pathway can lead to abnormal expression of a wide range of tumor-associated genes, regulation of the proliferation and apoptosis of cells, transformation of normal cells, and the formation and transfer of tumor vessels, which have direct impacts on the occurrence and progression of malignancies (23). Therefore, NF- $\mathrm{B}$ may be a key target for the prevention of human cancer. Baldwin (24) demonstrated that MAPK and NF- $\kappa \mathrm{B}$ signaling pathways are closely associated, and that the activation of $\mathrm{NF}-\kappa \mathrm{B}$ is indispensable for the oncogenes BCR-ABL and Ras transforming. Each molecule in the MAPK signaling pathway serves an important role in the activation of $N F-\kappa B$. Studies have shown that phosphorylation of ERK can promote the phosphorylation of IK kinase (IKK), which promotes the activation of $\mathrm{NF}-\kappa \mathrm{B}$; this is called the ERK-IKKs-I $\kappa$ B-NF- $\kappa \mathrm{B}$ signaling cascade $(25,26)$. The rapid and sustained activation of $\mathrm{P} 38$ caused by vitamin $\mathrm{C}$ inhibits the activation of IKK caused by tumor necrosis factor (TNF), while the use of a P38 inhibitor causes the increase of NF-кB (27). Baldwin (24) showed that the inactivation of cyclin D1/cyclin-dependent kinase 4 caused by P38 reduces the nuclear translocation of $\mathrm{NF}-\kappa \mathrm{B}$ in colorectal cancer. The inhibition of $\mathrm{P} 38$, JNK and NF- $\mathrm{NB}$ signaling pathways caused by disulfiram inhibits the performance of breast cancer stem cells (28). Baud and Karin (29) discovered that NF- $\kappa B$ and JNK signaling pathways are negatively associated. In gliomas, the inhibition of matrix metalloproteinase 2 reduces the activation of $N F-\kappa B$ mediated by $\mathrm{TNF}-\alpha$, and then causes the cell death mediated by JNK (30). The inhibition of $\mathrm{NF}-\kappa \mathrm{B}$ requires the activation of JNK, which is one of the mechanisms for apoptosis (31-33). A number of researchers have maintained that one of the possible mechanisms of cell apoptosis mediated by JNK3 may be that the transcription of $N F-\kappa B$ is arrested, followed by the phosphorylation of p65 protein by JNK3 $(34,35)$. In the present study, the expression of p-ERK and $\mathrm{NF}-\kappa \mathrm{B}$ decreased in a time-dependent manner, while p-P38 and p-JNK increased in a time-dependent manner in the $400 \mathrm{mg} / \mathrm{l}$ GPS group, which suggests that the apoptosis of $\mathrm{K} 562$ cells is caused by the inhibition of the MAPK/NF- $\kappa \mathrm{B}$ signaling pathway. However, the question whether all of the molecules in the MAPK signaling pathway are involved in the process of $\mathrm{NF}-\kappa \mathrm{B}$ activation or not requires further investigation.

The cell cycle consists the G1, S, G2 and M phases. Cell cycle checkpoints are used by the cell to monitor and regulate the progress of the cycle. Checkpoints prevent cell cycle progression at specific points, allowing verification of necessary phase processes and repair of DNA damage. The cell is not able to proceed to the next phase until checkpoint requirements have been met. Several checkpoints are designed to ensure that damaged or incomplete DNA is not passed on to daughter cells. Two primary checkpoints exist, including the G1/S checkpoint and the G2/M checkpoint. G1/S transition is a restriction point and a rate-limiting step in the cell cycle. An alternative model of the cell cycle's response to DNA damage has previously been proposed, and it is known as the post-replication checkpoint. In this response, two key classes of regulatory molecules, cyclins and CDKs, determine a cell's progress through the cell cycle (36). Cyclin D1 has the function of regulating cells entering the G1 phase. When cycling D1 is expressed at low levels, cells are arrested in the G1 phase. Regulation of cell cycle is one of the most important biological processes in cells, 
and disorders in the cycle can lead to malignancies. Cell cycle arrest may be a new target for the exploitation of novel drugs. However, the mechanism of effect of GPS on K562 cell cycle arrest remains unknown and further research is required. In the present study article, GPS was used to affect the growth of K562 cells, and it was discovered that the cell cycle was arrested in the G0/G1 phase, which was likely associated with the differentiation and apoptosis of leukemia cells.

Cyclin D1 is a member of the cyclin protein family that is involved in regulating cell cycle progression. The synthesis of cyclin D1 is initiated during the G1 phase, and its synthesis drives the G1/S phase transition. Overexpression of cyclin D1 enables persistent proliferation of cells and serves an important role in the process of carcinogenesis $(37,38)$. In particular, overexpression of cyclin D1 can be found in a variety of malignant tumors. Polynucleotide chains of cyclin D1 are adopted in the treatment of lung cancer (39). It has been found that cyclin D1 and p53 are the downstream target genes of $\mathrm{NF}-\kappa \mathrm{B} . \mathrm{NF}-\kappa \mathrm{B}$ regulates the expression of cyclin D1, and p53 arrests the cell cycle and inhibits the proliferation of tumor cells (40). Cyclin D1 promoter contains two binding sites for NF- $\kappa \mathrm{B}$. The activation of $\mathrm{NF}-\kappa \mathrm{B}$ has the function of promoting cyclin D1 expression and driving the G1/S phase, so that normal cells change to malignant cells (41). In this study, it was observed that NF- $\mathrm{NB}$ and cyclin D1 decreased in a time-dependent manner following treatment with GPS. It can be speculated that one of the probable mechanisms of the effect of GPS on K562 apoptosis may be that the inhibition of the MAPK/NF- $\mathrm{B}$-mediated signaling transduction pathway can inhibit the expression of cyclin D1, followed by the arrest if the cell cycle in the G0/G1 phase, which ultimately induces the apoptosis of K562 cells.

In conclusion, GPS can inhibit proliferation and induce apoptosis of K562 cells by arresting cell cycle at the $\mathrm{G} 0 / \mathrm{G} 1$ phase. In addition, the results demonstrated that $\mathrm{MAPK} / \mathrm{NF}-\kappa \mathrm{B} /$ cyclin D1 serves a crucial role in cell cycle arrest and the induction of apoptosis of K562 cells. Consequently, the MAPK/NF- $\mathrm{B} /$ cyclin D1 signaling pathway is a potential molecular target for the treatment of leukemia and has promising prospects.

\section{Acknowledgements}

The present study was supported by projects from the National Science Foundation of China (grant no. 81171929).

\section{References}

1. Levis M: Quizartinib in acute myeloid leukemia. Clin Adv Hematol Oncol 11: 586-588, 2013.

2. Cesaro S, De Filippi P, Di Meglio A, Leszl A, Donska S, Zaccaron A, Cagioni C, Galavotti R, Danesino C, Aprili F, et al: Different outcomes of allogeneic hematopoietic stem cell transplant in a pair of twins affected by juvenile myelomonocytic leukemia. Int J Hematol 99: 208-212, 2014.

3. Lu J, Huang X, Bao L, Jiang H, Zhu H and Jiang B: Treatment outcomes in relapsed acute promyelocytic leukemia patients initially treated with all-trans retinoic acid and arsenic compound-based combined therapies. Oncol Lett 7: 177-182, 2014

4. Hait WN, Choudhury S, Srimatkandada S and Murren JR: Sensitivity of K562 human chronic myelogenous leukemia blast cells transfected with a human multidrug resistance cDNA to cytotoxic drugs and differentiating agents. J Clin Invest 91: 2207-2215, 1993
5. Yang G, Li X, Li X, Wang L, Li J, Song X, Chen J, Guo Y, Sun X, Wang S, et al: Traditional Chinese medicine in cancer care: A review of case series published in the chinese literature. Evid Based Complement Alternat Med 2012: 751046, 2012.

6. Luo Y, Zhang P, Zeng HQ, Lou SF and Wang DX: Ginsenoside $\mathrm{Rg} 3$ induces apoptosis in human multiple myeloma cells via the activation of Bcl-2-associated X protein. Mol Med Rep 12: 3557-3562, 2015.

7. Lozzio CB and Lozzio BB: Human chronic myelogenous leukemia cell-line with positive Philadelphia chromosome. Blood 45: 321-334, 1975.

8. Gambari R and Fibach E: Medicinal chemistry of fetal hemoglobin inducers for treatment of beta-thalassemia. Curr Med Chem 14: 199-212, 2007.

9. Schnetzke U, Fischer M, Frietsch JJ, Finkensieper A, Clement JH, Hochhaus A and La Rosée P: Paradoxical MAPK-activation in response to treatment with tyrosine kinase inhibitors in CML: Flow cytometry loses track. Cytometry B Clin Cytom 86: 229-235, 2014.

10. Qi M and Elion EA: MAP kinase pathways. J Cell Sci 118 (Pt 16): 3569-3572, 2005

11. Kang CD, Yoo SD, Hwang BW, Kim KW, Kim DW, Kim CM, Kim SH and Chung BS: The inhibition of ERK/MAPK not the activation of JNK/SAPK is primarily required to induce apoptosis in chronic myelogenous leukemic K562 cells. Leuk Res 24: 527-534, 2000.

12. Zhao LY, Zhang J, Guo B, Yang J, Han J, Zhao XG, Wang XF, Liu LY, Li ZF, Song TS and Huang C: MECP2 promotes cell proliferation by activating ERK1/2 and inhibiting p38 activity in human hepatocellular carcinoma HEPG2 cells. Cell Mol Biol (Noisy-le-grand) Suppl 59: OL1876-OL1881, 2013.

13. Pal P, Kanaujiya JK, Lochab S, Tripathi SB, Bhatt ML, Singh PK, Sanyal S and Trivedi AK: 2-D gel electrophoresis-based proteomic analysis reveals that ormeloxifen induces G0-G1 growth arrest and ERK-mediated apoptosis in chronic myeloid leukemia cells K562OL. Proteomics 11: 1517-1529, 2011.

14. Obata T, Brown GE and Yaffe MB: MAP kinase pathways activated by stress: The p38 MAPK pathway. Crit Care Med 28 (Suppl 4): N67-N77, 2000.

15. Park EJ, Kiselev E, Conda-Sheridan M, Cushman M and Pezzuto JM: Induction of apoptosis by 3-amino-6-(3-aminopro pyl)-5,6-dihydro-5,11-dioxo-11H-indeno [1,2-c]isoquinoline via modulation of MAPKs (p38 and c-Jun N-terminal kinase) and c-Myc in HL-60 human leukemia cells. J Nat Prod 75: 378-384, 2012.

16. Zhang H, Wang HF, Liu Y, Huang LJ, Wang ZF and Li Y: The haematopoietic effect of Panax japonicus on blood deficiency model mice. J Ethnopharmacol 154: 818-824, 2014.

17. Li SS, Jin YP, Yao CL and Wang YP: Research achievements on structures and activities of polysaccharides from Panax ginseng. Zhongguo Zhong Yao Za Zhi 39: 4709-4715, 2014 (In Chinese).

18. Wang Z, Meng J, Xia Y, Meng Y, Du L, Zhang Z, Wang E and Shan F: Maturation of murine bone marrow dendritic cells induced by acidic Ginseng polysaccharides. Int J Biol Macromol 53: 93-100, 2013.

19. Kim HJ, Kim MH, Byon YY, Park JW, Jee Y and Joo HG: Radioprotective effects of an acidic polysaccharide of Panax ginseng on bone marrow cells. J Vet Sci 8: 39-44, 2007.

20. Bhattacharyya S, Ghosh J and Sil PC: Iron induces hepatocytes death via MAPK activation and mitochondria-dependent apoptotic pathway: Beneficial role of glycine. Free Radic Res 46: 1296-1307, 2012.

21. Ho PJ, Chou CK and Yeh SF: Role of JNK and p38 MAPK in Taiwanin A-induced cell death. Life Sci 91: 1358-1365, 2012.

22. Filomeni G, Piccirillo S, Rotilio G and Ciriolo MR: p38(MAPK) and ERK1/2 dictate cell death/survival response to different pro-oxidant stimuli via p53 and Nrf2 in neuroblastoma cells SH-SY5Y. Biochem Pharmacol 83: 1349-1357, 2012.

23. Reikvam H, Olsnes AM, Gjertsen BT, Ersvar E and Bruserud $\varnothing$ : Nuclear Factor-kappaB Signaling: A contributor in leukemogenesis and a target for pharmacological intervention in human acute myelogenous leukemia. Crit Rev Oncog 15: 1-41, 2009.

24. Baldwin AS: Control of oncogenesis and cancer therapy resistance by the transcription factor NF-kappaB. J Clin Invest 107: 241-246, 2001.

25. Wu CJ, Wang YH, Lin CJ, Chen HH and Chen YJ: Tetrandrine down-regulates ERK/NF- $\kappa \mathrm{B}$ signaling and inhibits activation of mesangial cells. Toxicol In Vitro 25: 1834-1840, 2011. 
26. Dia VP and Gonzalez de Mejia E: Lunasin potentiates the effect of oxaliplatin preventing outgrowth of colon cancer metastasis, binds to $\alpha 5 \beta 1$ integrin and suppresses FAK/ERK/NF- $\kappa \mathrm{B}$ signaling. Cancer Lett 313: 167-180, 2011.

27. Kato T Jr, Delhase M, Hoffmann A and Karin M: CK2 is a C-Terminal IkappaB kinase responsible for NF-kappaB activation during the UV response. Mol Cell 12: 829-839, 2003.

28. Bowie AG and O'Neill LA: Vitamin C inhibits NF-kappa B activation by TNF via the activation of $\mathrm{p} 38$ mitogen-activated protein kinase. J Immunol 165: 7180-7188, 2000.

29. Baud V and Karin M: Signal transduction by tumor necrosis factor and its relatives. Trends Cell Biol 11: 372-377, 2001.

30. Kesanakurti D, Chetty C, Bhoopathi P, Lakka SS, Gorantla B, Tsung AJ and Rao JS: Suppression of MMP-2 attenuates TNF- $\alpha$ induced NF- $\kappa \mathrm{B}$ activation and leads to JNK mediated cell death in glioma. PloS One 6: e19341, 2011.

31. Zhang S, Lin ZN, Yang CF, Shi X, Ong CN and Shen HM: Suppressed NF-kappaB and sustained JNK activation contribute to the sensitization effect of parthenolide to TNF-alpha-induced apoptosis in human cancer cells. Carcinogenesis 25: 2191-2199, 2004.

32. Lin A: Activation of the JNK signaling pathway: Breaking the brake on apoptosis. Bioessays 25: 17-24, 2003.

33. De Smaele E, Zazzeroni F, Papa S, Nguyen DU, Jin R, Jones J, Cong R and Franzoso G: Induction of gadd45beta by NF-kappaB downregulates pro-apoptotic JNK signalling. Nature 414: 308-313, 2001.

34. Boonyarat C, Yenjai C, Vajragupta O and Waiwut P: Heptaphylline induces apoptosis in human colon adenocarcinoma cells through bid and Akt/NF-kB (p65) pathways. Asian Pac J Cancer Prev 15: 10483-10487, 2014.
35. Wang Y: Attenuation of berberine on lipopolysaccharide-induced inflammatory and apoptosis responses in $\beta$-cells via TLR4-independent JNK/NF-кB pathway. Pharm Biol, 2013 (Epub ahead of print).

36. Wang CZ, Xie JT, Fishbein A, Aung HH, He H, Mehendale SR, He TC, Du W and Yuan CS: Antiproliferative effects of different plant parts of Panax notoginseng on SW480 human colorectal cancer cells. Phytother Res 23: 6-13, 2009.

37. Ozuysal S, Oztürk H, Bilgin T and Filiz G: Expression of cyclin D1 in normal, hyperplastic and neoplastic endometrium and its correlation with Ki-67 and clinicopathological variables. Arch Gynecol Obstet 271: 123-126, 2005.

38. Yan KX, Liu BC, Shi XL, You BR, Xu M, Kang N and Zhao CY: Role of cyclin D1 in carcinogenesis of human cells induced by quartz. Zhonghua Yu Fang Yi Xue Za Zhi 38: 396-399, 2004 (In Chinese).

39. Li ZL, Shao SH, Xie SY, Yue Z and Ma Y: Anti-sense nucleic acid of CyclinD1 induces apoptosis of lung adenocarcinoma cancer cell A549. Sheng Li Xue Bao 63: 261-266, 2011 (In Chinese).

40. Harlozińska A, Bar J and Montenarh M: Analysis of the immunoreactivity of three anti-p53 antibodies and estimation of the relations between p53 status and MDM2 protein expression in ovarian carcinomas. Anticancer Res 20: 1049-1056, 2000.

41. Manna SK and Aggarwal BB: All-trans-retinoic acid upregulates TNF receptors and potentiates TNF-induced activation of nuclear factors-kappaB, activated protein-1 and apoptosis in human lung cancer cells. Oncogene 19: 2110-2119, 2000. 